\title{
ANALISIS KOMPETENSI PEDAGOGIK GURU DALAM PELAKSANAAN KETERAMPILAN DASAR MENGAJAR PADA PEMBELAJARAN TEMATIK
}

\author{
Benedicta Monica Anindya Putri ${ }^{1}$, Mudzanatun ${ }^{2}$, Anggun Dwi Setya Putri ${ }^{3}$ \\ 1,2,3 Program Studi Pendidikan Guru Sekolah Dasar Fakultas IImu Pendidikan \\ Universitas PGRI Semarang \\ e-mail: benedictmo2009@gmail.com
}

\begin{abstract}
ABSTRAK
Tujuan yang hendak dicapai dalam penelitian ini adalah untuk mengetahui kompetensi pedagogik guru dalam pelaksanaan keterampilan dasar mengajar pada pembelajaran tematik kelas $\mathrm{V}$ SD Negeri Pandeanlamper 01 Semarang. Penelitian ini menggunakan pendekatan kualitatif dengan metode deskriptif. Subjek penelitian ini adalah guru kelas V SD Negeri Pandeanlamper 01 Semarang. Teknik pengumpulan data menggunakan metode observasi, wawancara, dan dokumentasi. Uji keabsahan data menggunakan ketekunan pengamatan dan uji kredibilitas dengan melakukan triangulasi data. Teknik analisis data menggunakan teknik model interaktif Miles \& Huberman ( reduksi data, penyajian data, dan penarikan kesimpulan). Hasil penelitian ini adalah analisis kompetensi pedagogik guru dalam pelaksanaan keterampilan dasar mengajar pada pembelajaran tematik kelas $\mathrm{V}$ SD Negeri Pandeanlamper 01 Semarang yakni ada 8 keterampilan dasar mengajar antara lain, keterampilan membuka dan menutup pelajaran, keterampilan menjelaskan, keterampilan bertanya, keterampilan memberi penguatan, keterampilan mengadakan variasi, keterampilan mengelola kelas, keterampilan membimbing diskusi kelompok, dan keterampilan mengajar perseorangan. Berdasarkan hasil penelitian tersebut, maka saran yang dapat diajukan dalam penelitian ini adalah bagi Kepala SD Negeri Pandeanlamper 01 Semarang, saran terbaik untuk lebih memperhatikan segala sesuatu yang berkaitan dengan perkembangan dan keadaan yang ada di sekolah, keadaan guru, karyawan, dan peserta didik. Bagi guru hendaknya selalu berusaha untuk meningkatkan keterampilan dasar mengajar dalam pelaksanaan pembelajaran. Tujuannya agar para peserta didik dapat belajar lebih giat. Serta dapat meningkatkan minat belajar peserta didik. Bagi para peneliti mendatang, disarankan untuk memperhatikan keterbatasan dalam penelitian ini sehingga penelitian yang akan datang dapat terlaksana secara baik.
\end{abstract}

Kata Kunci : Kompetensi Pedagogik,Guru,Keterampilan Dasar Mengajar.

\begin{abstract}
The purpose of this study is to determine the pedagogical competence of teachers in the implementation of basic teaching skills in the thematic learning of class V SD Negeri Pandeanlamper 01 Semarang. This study uses a qualitative approach with descriptive methods. The subject of this study is the fifth grade teacher at SD Negeri Pandeanlamper 01 Semarang. Data collection techniques use the method of observation, interviews, and documentation. The validity test of the data uses persistence of observation and credibility test by triangulating data. Data analysis techniques use the interactive model techniques Miles \& Huberman (data reduction, data presentation, and conclusion). The results of this study are teacher pedagogical competence analysis in the implementation of basic teaching skills in the thematic learning of class V SD Negeri Pandeanlamper 01 Semarang namely there are 8 basic teaching skills, among others, opening and closing lessons, explaining skills, asking skills, giving reinforcement skills, holding skills variation, classroom management skills, guiding group discussion skills, and individual teaching skills.Based on these results, the advice that can be submitted in this study is for the Principal of SD Negeri Pandeanlamper 01 Semarang, the best advice is to pay more attention to everything related to developments and conditions in the school, the situation of teachers, employees, and students. For teachers should always try to improve basic teaching skills in the implementation of learning. The goal is that students can study harder and can increase student interest in learning. For future researchers, it is advisable to pay attention to limitations in this study so that future research can be carried out properly.
\end{abstract}

Keywords : Pedagogical Competence, Teacher,Basic Teaching Skills. 


\section{Pendahuluan}

Pendidikan memegang peranan penting dalam mempersiapkan sumber daya manusia yang berkualitas dan mampu berkompetisi dalam perkembangan ilmu pengetahuan dan teknologi, sehingga pendidikan harus dilaksanakan dengan sebaikbaiknya untuk memperoleh prestasi belajar yang maksimal. Hal tersebut dapat dicapai dengan terlaksananya pendidikan yang tepat waktu dan tepat guna untuk mencapai tujuanp pembelajaran. Pembelajaran matematika di sekolah merupakan salah satu komponen pendidikan yang tidak hanya mengembangkan kemampuan dan keterampilan menerapkan matematika, melainkan mengembangkan kemampuan memecahkan masalah (Wijayanti, 2014).

Pendidikan merupakan sarana penting untuk meningkatkan kualitas sumber daya manusia (SDM) dalam menjamin keberlangsungan pembangunan suatu bangsa. Usman (2006: 2) mengungkapkan bahwa salah satu masalah yang dihadapi dunia pendidikan kita adalah masalah lemahnya proses pembelajaran. Proses pembelajaran merupakan inti dari proses pendidikan secara keseluruhan dengan guru sebagai pemegang peranan utama. Hal tersebut juga diatur dalam Peraturan Menteri Pendidikan Dan Kebudayaan Nomor 22 Tahun 2016 Tentang Standar Proses Pendidikan Dasar Dan Menengah menyatakan bahwa Standar Proses adalah kriteria mengenai pelaksanaan pembelajaran pada satuan pendidikan untuk mencapai Standar Kompetensi Lulusan. Dengan demikian, standar proses pendidikan dimaksudkan dapat dijadikan pedoman bagi guru dalam pengelolaan pembelajaran.

Keberhasilan belajar peserta didik dipengaruhi oleh beberapa faktor, dapat berasal dari diri peserta didik sendiri maupun dari guru sebagai pendidik. Faktor yang berasal dari guru di antaranya kemampuan dalam merancang pembelajaran yang mampu menumbuhkan motivasi belajar peserta didik, menciptakan suasana belajar yang menarik dan menyenangkan. Namun pada kenyataannya, peserta didik masih menganggap matematika sebagai mata pelajaran yang menakutkan sehingga susah untuk dipahami. Hal ini terjadi karena pendidik belum mampu mengemas pembelajaran matematika menjadi lebih menyenangkan yang mampu menarik perhatian peserta didik. Sehingga membuat prestasi belajar peserta didik tidak sesuai dengan yang diharapkan (Ayuwanti, 2016).

Guru merupakan komponen penting dalam proses pendidikan. Di Indonesia, guru belum sepenuhnya melaksanakan kegiatan belajar mengajar dengan baik. Saud (2012: 3-4) yang menyatakan bahwa guru yang profesional adalah guru yang dapat melakukan tugas mengajarnya dengan baik. Terkait peran dan tugas guru, maka guru memerlukan kualifikasi khusus. Mengenai kualifikasi guru, telah dijelaskan dalam Undang-Undang Republik Indonesia No. 14 Tahun 2005 Tentang Guru dan Dosen Bab IV Pasal 8, menyatakan bahwa, "guru wajib memiliki kualifikasi akademik, kompetensi, sertifikat pendidik, sehat jasmani dan rohani, serta memiliki kemampuan untuk mewujudkan tujuan pendidikan nasional."

Dalam kaitan ini Earl V. Pullias dan James D. Young (1968)9 dalam bukunya A Teacher Is a Many Thing mengutarakan ada empat belas karakteristik yang melekat pada guru yang unggul itu adalah sebagai berikut:(guru sebagai guru), (Guru sebagai teladan), (Guru sebagai penasihat), (Guru sebagai pemegang otoritas), (Guru sebagai pembaharu), (Guru sebagai pemandu), (Guru sebagai pelaksana tugas rutin), (Guru sebagai insan visioner), (Guru sebagai pencipta), (Guru sebagai orang yang realistis), (Guru sebagai penutur cerita dan seorang actor), (Guru sebagai pembongkar kemah), (Guru sebagai peneliti), (Guru sebagai penilai) (Kirom, 2017).

Salah satu kualifikasi yang harus dipenuhi oleh guru ialah kompetensi. Adapun kompetensi yang harus dimiliki oleh guru yaitu, kompetensi pedagogik, kepribadian, sosial, dan profesional. Mengenai hal ini, telah dijelaskan sebelumnya dalam undang-undang yang sama bab IV Pasal 10 ayat 1, bahwa kompetensi guru sebagaimana dimaksud dalam Pasal 8 meliputi kompetensi pedagogik, kompetensi kepribadian, kompetensi sosial, dan kompetensi profesional yang diperoleh melalui pendidikan profesi. Salah satu kompetensi yang harus dimiliki guru ialah kompetensi pedagogik. Kompetensi pedagogik merupakan 
kemampuan guru dalam pengelolaan pembelajaran peserta didik yang sekurang-kurangnya memiliki pemahaman wawasan atau landasan kependidikan.

Dalam proses pembelajaran, kompetensi pedagogik mempunyai peranan yang penting karena berhubungan langsung dengan tugas pokok seorang guru, yakni terkait dengan kemampuan yang terfokus pada pelaksanaan proses belajar mengajar dan pengelola proses pembelajaran. Oleh karena itu, guru harus memiliki keahlian dalam pembelajaran. Dalam hal ini keterampilan gurulah yang dibutuhkan untuk pembelajaran agar anak didik tidak jenuh. Sehingga untuk dapat menciptakan kualitas pembelajaran yang efektif dan menyenangkan perlu untuk menerapkan keterampilan dasar mengajar Mulyasa (2013: 32), menguasai keterampilan dasar mengajar ini menjadi penting bagi guru guna menyempurnakan kompetensi pedagogik guru. Selain itu, keterampilan dasar mengajar juga merupakan komponen yang mengintegrasikan berbagai kompetensi guru secara utuh dan menyeluruh.

Keterampilan dasar mengajar adalah kemampuan atau keterampilan yang bersifat khusus yang harus dimiliki oleh guru agar dapat melaksanakan tugas mengajar secara efektif, efisien dan profensional. Keterampilan dasar mengajar inilah yang harus dimiliki oleh seorang guru sebagai modal awal untuk melaksanakan tugas-tugas pembelajarannya secara terencana dan profesional. Menerapkan keterampilan dasar mengajar merupakan keterampilan yang harus dikuasai guru dalam pembelajaran karena dengan menerapkan keterampilan tersebut dapat meningkatkan kualitas pembelajaran menjadi lebih baik, serta dengan memiliki keterampilan dasar mengajar, guru dapat mengelola proses pembelajaran dengan baik yang berimplikasi pada peningkatan kualitas lulusan sekolah. Saud (2012: 2), keterampilan dasar mengajar guru dalam proses belajar mengajar antara lain: 1) keterampilan membuka dan menutup pelajaran, 2) keterampilan menjelaskan, 3) keterampilan bertanya, 4) keterampilan mengadakan variasi, 5) keterampilan memberi penguatan, 6) keterampilan mengelola kelas, 7) keterampilan membimbing diskusi kelompok kecil, dan 8) keterampilan mengajar perorangan atau kelompok kecil.

Studi pendahuluan peneliti diperdalam dengan mengamati lbu Rusmiati mengajar di kelas $\mathrm{V}$ A. Pengamatan peneliti menghasilkan temuan dalam studi pendahuluan ini, bahwa Ibu Rusmiati belum sepenuhnya melaksanakan keterampilan dasar mengajar. Peneliti mengamati bahwa Ibu Rusmiati cenderung memilih menggunakan pola tradisional. Padahal delapan keterampilan dasar mengajar sangat berperan dalam menentukan kualitas pembelajaran. Sehingga pembelajaran yang berlangsung kurang efektif, monoton, membuat peserta didik bosan, dan cenderung tidak diperhatikan oleh peserta didik.

Berdasarkan wawancara tidak terstruktur dari studi pendahuluan, guru yang akan diteliti yaitu guru kelas V Ibu Rusmiati, S.Pd., sudah berstatus pegawai negeri sipil dan memiliki sertifikat pendidik. Beliau memiliki pengalaman mengajar 31 tahun. Akan tetapi, Ibu Rusmiati belum sepenuhnya tau dan paham mengenai penerapan keterampilan dasar mengajar guru dalam pembelajaran. Ibu Rusmiati mengungkapkan bahwa masih ada sebagian peserta didik yang kurang antusias dalam mengikuti pembelajaran dan terkadang mengobrol atau bicara sendiri saat guru menjelaskan materi. Menurut lbu Rusmiati, hal tersebut masih wajar jikalau hanya beberapa peserta didik yang kurang antusias atau malah mengobrol sendiri di dalam kelas. Hasil pembagian angket orangtua menyatakan anak berperilaku baik dilingkungan keluarga dan orang tua merasa kaget dan tidak menyangka hal tersebut dapat terjadi pada anak.

\section{Metode}

Penelitian ini menggunakan pendekatan kualitatif dengan metode deskriptif. Penelitian ini dilaksanakan di SD Negeri Pandeanlamper 01 Semarang khususnya di kelas 5. SD Negeri Pandeanlamper 01 terletak di Jalan Brigjend Sudiarto No. 105, Kota Semarang. Penelitian ini dilaksanakan pada tanggal 13 sampai 15 Januari 2020. Subjek dalam penelitian ini yaitu guru kelas V SD Negeri Pandeanlamper 01 Semarang. Sumber data utama dalam penelitian ini adalah kata-kata dan tindakan, sumber data tertulis, foto yang bersumber dari responden dan peneliti. Teknik pengumpulan data dalam penelitian ini adalah observasi, wawancara, dan dokumentasi. 
Instrumen dalam penelitian ini berupa peneliti (Human instrument), lembar observasi, pedoman wawancara, dan dokumentasi. Penelitian ini menggunakan teknik analisis Miles \& Huberman, yang aktivitas dalam analisis data kualitatif selama dilapangan yaitu data reduction, data display, conclusion drawing/verification. Uji keabsahan data dalam penelitian ini menggunakan uji ketekunan pengamatan dan dan uji kredibilitas dengan melakukan triangulasi data.

\section{Hasil dan Pembahasan}

1. Keterampilan Membuka dan Menutup Pelajaran

Ibu Rusmiati memberikan "motivation of today" sesuai dengan tema materi yang akan dipelajari. Sehingga peserta didik mendapat suntikan motivasi dalam setiap awal pembelajaran. Setelah itu, Beliau mengemukakan tema, sub tema, dan pembelajaran yang akan dilaksanakan peserta didik pada hari itu. Kedua hal tersebut meningkatkan semangat dan minat peserta didik. Ibu Rusmiati juga melakukan apersepsi untuk mengadakan kaitan antar aspek yang relevan dan membandingkan pengetahuan baru dan yang telah diketahui peserta didik. Semua itu merupakan kegiatan membuka pelajaran yang sesuai dengan teori keterampilan membuka pelajaran. Sehingga lbu Rusmiati guru kelas V telah menerapkan keterampilan ini dengan baik.

Adapun dalam kegiatan menutup pelajaran, Ibu Rusmiati mengadakan tinjauan ulang seperti membuat ringkasan atau menerangkan kembali inti dari pembelajaran yang telah dilalui. Kemudian dilanjutkan dengan kegiatan penyimpulan dan mengadakan evaluasi dalam bentuk soal latihan. Hal tersebut menunjukkan bahwa komponen-komponen dari keterampilan menutup pelajaran ada di dalamnya. Sehingga lbu Rusmiati telah menerapkan keterampilan ini dengan baik pula.

\section{Keterampilan Menjelaskan}

Guru kelas V yaitu Ibu Rusmiati telah terampil dalam menjelaskan. Hal ini dibuktikan dengan kata-kata pendidik yang efektif dan efisien dalam menjelaskan. Menjelaskan dengan kata sederhana dan mudah ditangkap oleh peserta didik. Ketika ada istilah asing yang belum diktehaui peserta didik, pendidik akan menjelaskan dengan singkat, padat dan jelas. Sekolah telah mengaplikasikan Kurikulum 2013 dalam pembelajaran di SD Negeri Pandeanlamper 01 Semarang, jadi secara otomatis pendidik mengaplikasikan pembelajaran seperti alur yang ada dalam buku pegangan guru. Sehingga dalam memberikan pembelajaran khususnya dalam memberikan penjelasan tersusun secara logis dan sistematis. Menjelaskan dari yang sederhana menuju penjelasan yang kompleks. Tidak jarang lbu Rusmiati juga menekankan poin-poin penting dengan meminta peserta didik menggarisbawahi atau membuat akronim untuk memudahkan hafalan peserta didik tentang poin penting tersebut.

Adapun penggunaan contoh yang dilakukan oleh Ibu Rusmiati juga jelas, relevan dan sesuai dengan kemampuan peserta didik yang menangkapnya. Beragam variasi dalam memberikan contoh juga telah dipraktikkan oleh Ibu Rusmiati. Mulai dari peristiwa dalam kehidupan sehari-hari hingga cara penyampaian contoh melalui dialog bahkan melalui gambar dan video pembelajaran. Terlihat respon peserta didik dengan memberikan tanggapan, pendapat, dan bahkan pertanyaan. Berdasarkan pemaparan di atas, menunjukkan bahwa lbu Rusmiati guru kelas $\mathrm{V}$ telah melaksanakan keterampilan menjelaskan dengan baik. Hal ini dibuktikan dengan diterapkannya semua komponen dalam keterampilan menjelaskan. Komponen-komponen yang menyusun keterampilan menjelaskan sesuai dengan teori yang telah dipaparkan penulis dalam bab II.

\section{Keterampilan Bertanya}

Salah satu cara Ibu Rusmiati dalam melakukan keterampilan bertanya yaitu dengan melakukan apersepsi. Apersepsi dilakukan untuk memancing peserta didik agar berani berbicara dan mengemukakan pendapatnya. Setiap memulai bab baru atau materi baru pendidik akan melakukan apersepsi ini dengan bertanya kepada peserta didik apa yang 
diingatnya dari pelajaran sebelumnya dan menanyakan keterkaitannya dengan yang akan dipelajari. Ini terlihat bahwa pendidik berusaha memberikan acuan dan dorongan agar peserta didik berani berpendapat dan berbicara. Melihat contoh pertanyaan yang diberikan kepada peserta didik seperti "Ada yang pernah ikut api unggun saat berkemah?" atau "Bagaimana rasanya berada didekat api unggun?" memperlihatkan bahwa pertanyaan yang dilontarkan sudah menggunakan bahasa yang jelas dan singkat. Sehingga pertanyaan tidak berbelit dan mudah ditangkap oleh peserta didik.

Kemudian Ibu Rusmiati terlihat jelas dalam memusatkan pertanyaan yang diberikan. Pertanyaan tentang peristiwa api unggun tersebut pertama ditujukan kepada seluruh kelas kemudian setelah pendidik merasa memberi jeda waktu berpikir kepada peserta didik, baru pendidik menanyakan kepada beberapa peserta didik tertentu. Selanjutnya, beberapa peserta didik mengacungkan tangan untuk menjawab. Pertanyaan tersebut kembali ditanyakan kepada peserta didik lain dan begitu seterusnya. Hal tersebut memperlihatkan bahwa pendidik memberikan jeda waktu berpikir dan melakukan pemindahan giliran untuk pemerataan pertanyaan. Setelah mendengar jawaban-jawaban peserta didik yang relawan memberikan jawaban tanpa ditunjuk atau yang sengaja ditanyai, Ibu Rusmiati juga untuk menerangkan kembali dengan singkat penjelasan-penjelasan sebelumnya. Memberikan penjelasan singkat tersebut menunjukkan bahwa Beliau memberikan tuntunan dengan merespon sekaligus membimbimbing peserta didik yang masih kurang tepat dalam menjawab pertanyaan. Hal demikian dilakukan pada semua pembelajaran yang diteliti oleh penulis. Berdasarkan pemaparan di atas, menunjukkan bahwa lbu Rusmiati guru kelas $\mathrm{V}$ telah mampu menerapkan keterampilan bertanya dengan baik. Hal ini terbukti bahwa mereka mengaplikasikan semua komponen-komponen yang ada dalam teori keterampilan bertanya.

\section{Keterampilan Memberi Penguatan}

Setiap peserta didik tertentu yang memberi respon positif atau jawaban atas pertanyaan yang diajukan oleh pendidik, pendidik selalu memberikan respon yang positif meskipun terkadang jawaban peserta didik masih kurang. Respon tersebut biasanya dalam bentuk verbal seperti mengatakan "bagus sekali", "tepat sekali", "luar biasa". Selain itu ketika peserta didik berani berbicara mengutarakan jawaban atau pendapat yang diajukan pendidik, pendidik selalu memberika nilai plus atau penghargaan berupa uang jajan tambahan untuk menghargai usaha mereka yang berani berbicara dan berpendapat di depan kelas.

Dalam pemberian penguatan secara verbal tersebut, pendidik juga menunjukkan penguatan secara gestural. Hal ini dapat diamati dari mimik pendidik yang terlihat cerah dan senang melihat peserta didik berpartisipasi, aktif, dan antusias dalam kegiatan pembelajaran. Selain itu tak jarang guru memberikan penguatan gestural dengan mendekati, memberikan acungan jempol dan memberikan applause. Pemaparan di atas menunjukkan bahwa lbu Rusmiati guru kelas $\mathrm{V}$ telah menerapkan pemberian penguatan dengan beragam cara dan melakukannya dengan sebaik serta seoptimal mungkin. Bukti mengatakan selama penelitian di SD Negeri Pandeanlamper 01 Semaranga, tidak terlihat sama sekali bahwa pendidik acuh tak acuh terhadap peserta didik bahkan cenderung hangat dan dekat dengan peserta didiknya. Pendidik tidak pernah menggunkan respon yang negatif, baik dalam bentuk verbal maupun gestural. Hal itu dikarenakan para lbu Rusmiati paham bahwa pemberian respon negatif seperti celaan, omelan dan kekerasan fisik hanya memberikan pendidikan yang buruk dan tercela.

\section{Keterampilan Mengadakan Variasi}

Ibu Rusmiati telah melaksanakan variasi dalam gaya mengajarnya. Hal ini terlihat ketika Beliau memberikan pembelajaran mengadakan variasi dari suara, mimik, gerak badan, kontak pandang dan perubahan posisi yang dilakukan. Seperti mengeraskan dan menekankan suara pada butir-butir penting, pemberian isyarat yang cocok, mimik dan gerakan badan yang sesuai dengan penyampaian isi materi. Ibu Rusmiati telah memaksimalkan penggunaan media audio visual. Seperti dalam pembelajaran praktik 
peristiwa konduksi, konveksi, dan radiasi dalam kehidupan sehari-hari, Beliau menggunakan LCD untuk mendukung kegiatan pembelajaran di dalam kelas. Hal ini sangat membantu untuk menampilkan PPT, video, ataupun gambar yang relevan dengan pembelajaran.

$\mathrm{Hal}$ ini menggambarkan bahwa pendidik menerapkan variasi dalam penggunaan media belajar. Mencermati penjelasan di atas memberikan kesimpulan bahwa guru di MAN Temanggung telah mampu menerapkan keterampilan mengadakan variasi dengan baik. Hal ini dibuktikan dengan diterapkannya komponen-komponen yang menyusun keterampilan mengadakan variasi sesuai dengan teori yang telah dipaparkan penulis dalam bab II.

\section{Keterampilan Mengelola Kelas}

Penunjukan sikap tanggap terlihat jelas ketika pendidik memberi reaksi terhadap peserta didik yang mengganggu dan mengacau kelas dengan menegur dan memberi pertanyaan kepada pengganggu dan pengacau tersebut. Peneguran dilakukan dengan jelas, tegas, tertuju dan menghindari respon negatif. Kemudian pembagian perhatian juga telah dilaksanakan Ibu Rusmiati dengan berkeliling dan sapaan. Selain itu, Beliau juga meminta peserta didik untuk menunjukkan tugasnya sehingga terlihat bahwa pendidik sedang menuntut tanggung jawab peserta didiknya. Pengarahan dan pemberian petunjuk juga jelas terarah kepada siapa dan bagaimana. Jadi, dapat dikatakan bahwa Ibu Rusmiati guru kelas $\mathrm{V}$ telah melaksanakan keterampilan mengelola kelas ini dengan baik sehingga penciptaan kondisi belajar yang optimal dapat dilakukan dengan baik pula

\section{Keterampilan Membimbing Diskusi Kelompok Kecil}

Tema, sub tema, pembelajaran, dan tujuan pembelajaran telah jelas dan selalu disampaikan pada awal pembelajaran sebelum diskusi dimulai. Ibu Rusmiati cenderung langsung menginstruksikan kelompok agar setiap anggota mengambil peran, mulai dari tugas mencatat hasil diskusi, presenter, dan yang lain diminta untuk mendiskusikan bersama. Usaha untuk meningkatkan partisipasi dan kontribusi peserta didik dalam diskusi belum terlihat juga terlihat dalam saat penelitian. Terbukti lbu Rusmiati melakukan pembagian tugas masing-masing dalam setiap kelompoknya. Pemberian kesempatan dalam mengungkapkan pendapat belum sepenuhnya dilaksanakan oleh lbu Rusmiati. Terlihat disaat satu kelompok mempresentasikan hasil diskusi, Ibu Rusmiati tidak mengarahkan anggota kelompok lain untuk menyimak dan memperhatikan presentasi yang sedang berlangsung. Sehingga, didapat pengamatan bahwa diskusi kelas tersebut belum maksimal karena Ibu Rusmiati belum mampu mengarahkan peserta didik untuk fokus kepada teman yang sedang presentasi dan belum adanya tanya jawab antara presenter dan audience.

Kemudian saat menutup diskusi, Ibu Rusmiati melakukan rangkuman dengan menyimpulkan poin-poin penting dari setiap presentasi yang dilakukan. Hal tersebut sesuai dengan teori tentang keterampilan membimbing diskusi kelompok kecil untuk menutup diskusi dengan memberikan rangkuman dan penialain terhadap diskusi yang telah berlangsung. Berdasarkan pemaparan di atas, dapat dilihat bahwa Ibu Rusmiati guru kelas V telah belum mampu melaksanakan keterampilan membimbing diskusi kelompok kecil dengan baik dan optimal karena ada komponen keterampilan yang belum mampu dilaksanakan.

\section{Keterampilan Mengajar Perseorangan}

Keterampilan ini erat kaitanyannya dengan pemberian perhatian terhadap setiap peserta didik dan menjalin hubungan yang lebih akrab antara pendidik dengan peserta didik. Hal ini dilakukan Ibu Rusmiati dengan cara memberikan tugas kepada peserta didik. Dengan pemberian tugas tersebut dapat membantu hubungan yang akrab antara pendidik dengan peserta didik. Selain itu, Ibu Rusmiati juga mempersilahkan peserta didik untuk bertanya meski di luar jam pelajaran atau juga mempersilakan mengirim pesan melalui whatsapp dan datang ke rumah. Hal ini guna membantu peserta didik dalam pembelajarannya agar optimal dan maksimal. Hubungan mereka begitu terasa harmonis satu sama lain sehingga kehangatan dan kepekaan antara peserta didik dan pendidik begitu kuat. Pemerataan perhatian dan kasih sayang kepada seluruh peserta didik juga terasa ketika masuk ke dalam 
masing-masing kelas. Pemaparan di atas menunjukkan bahwa lbu Rusmiati guru kelas $\mathrm{V}$ di SD Negeri Pandeanlamper 01 telah melaksanakan keterampilan mengajar perseorangan dengan baik.

\section{Simpulan dan Saran}

Berdasarkan tujuan, simpulan dari penelitian ini adalah analisis kompetensi pedagogik guru dalam pelaksanaan keterampilan dasar mengajar pada pembelajaran tematik kelas $\mathrm{V}$ SD Negeri Pandeanlamper 01 Semarang yakni ada 8 keterampilan dasar mengajar antara lain, keterampilan membuka dan menutup pelajaran, keterampilan menjelaskan, keterampilan bertanya, keterampilan memberi penguatan, keterampilan mengadakan variasi, keterampilan mengelola kelas, keterampilan membimbing diskusi kelompok, dan keterampilan mengajar perseorangan.

Pada pelaksanaan keterampilan membuka dan menutup pelajaran, keterampilan menjelaskan, keterampilan bertanya, keterampilan memberi penguatan, keterampilan mengadakan variasi, keterampilan mengelola kelas, dan keterampilan mengajar perseorangan sudah dilaksanakan dengan baik dan optimal sesuai dengan teori yang dikemukakan oleh para ahli pendidikan. Tetapi, pada pelaksanaan keterampilan membimbing diskusi kelompok belum dilaksanakan dengan optimal karena ada beberapa komponen yang belum terlaksana sepenuhnya..

Berdasarkan penelitian yang berjudul "Analisis Kompetensi Pedagogik Guru dalam Pelaksanaan Keterampilan Dasar Mengajar pada Pembelajaran Tematik Kelas V SD Negeri Pandeanlamper 01 Semarang", maka peneliti menyarankan hal-hal sebagai berikut untuk ditindaklanjuti yaitu:

1. Bagi Kepala SD Negeri Pandeanlamper 01 Semarang

a. Saran terbaik untuk lebih memperhatikan segala sesuatu yang berkaitan dengan perkembangan dan keadaan yang ada di sekolah, keadaan guru, karyawan, dan peserta didik,

b. Kepala Sekolah juga memberi masukan khususnya pada guru agar guru tersebut lebih aktif dan memperhatikan kondisi peserta didik pada saat proses belajar-mengajar berlangsung.

2. Bagi Guru

Hendaknya selalu berusaha untuk meningkatkan keterampilan dasar mengajar dalam pelaksanaan pembelajaran. Tujuannya agar para peserta didik dapat belajar lebih giat. Serta dapat meningkatkan minat belajar peserta didik.

3. Bagi Peneliti

Bagi para peneliti mendatang, disarankan untuk memperhatikan keterbatasan dalam penelitian ini sehingga penelitian yang akan datang dapat terlaksana secara baik.

\section{Daftar Pustaka}

Ayuwanti, Irma. 2016. Meningkatkan Aktivitas Dan Hasil Belajar Matematika Menggunakan Model Pembelajaran Kooperatif Tipe Group Investigation Di Smk Tuma'ninah Yasin Metro . Jurnal SAP Vol. 1 No. 2 Desember 2016.

Basuki, Habib Try. 2017. "Analisis Keterampilan Dasar Mengajar Guru Dalam Pembelajaran Di Kelas IV SD Negeri 03 Nglebak Tawangmangu.” Jurnal UMS. Volume 3, Nomor 2, halaman 1-14. http://eprints.ums.ac.id/56830/1/NASKAH\%20PUBLIKASI.pdf Diakses pada tanggal 2 September 2019 pukul 19.23.

Bektiarso, Singgih. 2015. Strategi Pembelajaran. Yogyakarta : LaksBang PRESSindo.

Daryanto. 2014. Pembelajaran Tematik, Terpadu, Terintegrasi (Kurikukum 2013). Yogyakarta : Gava Media. 
Kirom, Askhabul. 2017. Peran Guru Dan Peserta Didik Dalam Proses Pembelajaran Berbasis Multikultural . Jurnal Pendidikan Agama Islam Volume 3, Nomor 1, Desember 2017.

Kristiana, Dini dan A. Muhibbin. 2018. "Keterampilan Dasar Mengajar Dalam Pembelajaran Matematika Di SMP" Managemen Pendidikan. Volume 13, Nomor 2, halaman 204209.

Lampiran Peraturan Menteri Pendidikan Nasional No.16 Tahun 2007 tentang Standar Kualifikasi Akademik dan Kompetensi Guru.

Marno dan M. Idris. 2014. Strategi, Metode, dan Teknik Mengajar:Menciptakan Keterampilan Mengajar yang Efektif \& Edukatif. Yogyakarta : Ar-Ruzz Media.

Moleong, Lexy J. 2014. Metodologi Penelitian Kualitatif. Bandung: Remaja Rosdakarya.

Mulyasa, E. 2008. Standar Kompetensi dan Sertifikasi Guru, Cet. 3, Bandung: PT. Rosdakarya.

Mulyasa, E. 2015. Guru dalam Implementasi Kurikulum 2013. Bandung: PT. Rosdakarya.

Peraturan Menteri Pendidikan Dan Kebudayaan Nomor 22 Tahun 2016 Tentang Standar Proses Pendidikan Dasar Dan Menengah.

Peraturan Pemerintah Nomor 74 Tahun 2008 tentang Guru.

Peratutan Pemerintah No. 19 Tahun 2005 tentang Standar Nasional pendidikan.

Saud, Udin Syaefudin. 2012. Pengembangan Profesi Guru. Bandung : Alfabeta.

Shintia Revina. 2019. Skor PISA Melorot, Disparitas dan Mutu Guru Penyebab Utama. Artikel. https://edukasi.kompas.com/read/2019/12/07/13524501/skor-pisa-melorotdisparitas-dan-mutu-guru-penyebab-utama?page=all

Diakses pada tanggal 8 Desember 2019 pukul 21.25.

Sugiyono. 2014. Memahami Penelitian Kualitatif. Bandung: Alfabeta.

Suyadi. 2012. Strategi Pembelajaran Pendidikan Karakter. Bandung : PT. Remaja Rosdakarya Offset.

Undang-Undang Republik Indonesia No. 14 Tahun 2005 Tentang Guru dan Dosen.

Undang-Undang No. 20 tahun 2003 tentang Sistem Pendidikan Nasional.

Usman, Moh. Uzer. 2006. Menjadi Guru Profesional. Bandung : PT. Remaja Rosdakarya.

Wijayanti, Takdir Sukmo . 2014. Meningkatkan Minat Dan Prestasi Belajar Matematika Dengan Model Pembelajaran Group Investigation Siswa Kelas Vii A Smp Negeri 1 Polanharjo Klaten . Jurnal Pendidikan Matematika Vol 2 No 1, November 2014. 